Article

\title{
Energy Security and Portfolio Diversification: Conventional and Novel Perspectives
}

\author{
Carlo Andrea Bollino 1,2,*(D) and Philipp Galkin ${ }^{3}$ \\ 1 Department of Economics, University of Perugia, 06019 Perugia, Italy \\ 2 Visiting Energy and Macroeconomic Program, KAPSARC, Riyadh 11672, Saudi Arabia \\ 3 Visiting Energy Markets Program, KAPSARC, Riyadh 11672, Saudi Arabia; philipp.galkin@kapsarc.org \\ * Correspondence: carloandrea.bollino@unipg.it
}

Citation: Bollino, C.A.; Galkin, P. Energy Security and Portfolio Diversification: Conventional and Novel Perspectives. Energies 2021, 14, 4257. https://doi.org/10.3390/ en14144257

Academic Editor: Pierre Desrochers

Received: 19 May 2021

Accepted: 12 July 2021

Published: 14 July 2021

Publisher's Note: MDPI stays neutral with regard to jurisdictional claims in published maps and institutional affiliations.

Copyright: (c) 2021 by the authors. Licensee MDPI, Basel, Switzerland. This article is an open access article distributed under the terms and conditions of the Creative Commons Attribution (CC BY) license (https:// creativecommons.org/licenses/by/ $4.0 /)$.

\begin{abstract}
Despite the recent expansion of the scope, the main pillars of energy security remain physical supply and price components. This paper highlights the novel developments of this notion, including the exporters' perspective, relevant challenges, indicators, and policies. Furthermore, we apply the portfolio theory approach to five Gulf Cooperation Council countries to construct portfolios representing the trade-offs between maximizing returns (oil export growth or export prices) and minimizing risks (standard deviation of return variables). We assess portfolios' resilience to external demand and logistical shocks by running several disruptive scenarios. We find that oil exporters adopt a balanced approach to the risks associated with export volume growth and pricing, which is different from some major oil importers that prioritize either the physical supply or price stability. Simulation scenarios of increasing oil exports to China would have a significant impact mainly on Saudi Arabia and the United Arab Emirates (UAE), but not on the others, while scenarios of reduced oil exports to the United States would impact mainly Saudi Arabia and Kuwait. A blockade of the Malacca Strait would reduce export volumes and increase portfolio risks for all five economies, with Kuwait and Oman most affected.
\end{abstract}

Keywords: oil exports; GCC countries; energy security; portfolio optimization; risk diversification

\section{Introduction: The Bounds of Conventional Approaches to Energy Security}

\subsection{Creeping Scope vs. Immutable Priorities}

Since the outburst of the oil shock in the early 1970s, energy security has emerged as a relevant topic for scientific research as well as for policymakers and commercial market operators [1]. The initial concept was that of "assuring sufficient energy supplies", as set forth in the following decades by [2,3]. After the disruption of Fall 1973, the western countries, which were then the major oil importing countries, rendered the notion of energy security a notion of supply availability. In other words, the physical quantity is all that matters. After the beginning of the year 2000, a large and growing number of studies started to investigate other dimensions of energy security, answering a growing demand coming from international organizations and governments. In particular, there has been a progressive attention to include an economic perspective, inserting into the picture the price, after the oil price fluctuations resulting from the 1990-1991 Gulf War. A primary research focus was on the concept of economic affordability of energy and its impact on national welfare $[4,5]$.

Nowadays, the concept of energy security has been recast to include an extensive list of issues, including infrastructure [6], environmental impact [7], societal effects [8], energy efficiency [9], and governance [10,11], among others. The issue of oil price shocks remains relevant from the viewpoint of their impacts on financial markets variability [12] A new paradigm of energy security is now including the notion of diversification and of interdependence, hinting at geographical and technological diversification. However, this new paradigm appears too broad, with the risk of including any energy issue in the 
notion of energy security. We note that the viewpoint of the main international energy organizations has attempted to redefine energy security along these lines. We report below some definitions adopted by the main international organizations:

- $\quad$ The International Energy Agency speaks of "uninterrupted availability of energy sources at an affordable price" [13];

- The United Nations advocate a world where there is "the continuous availability of energy, in varied forms, in sufficient quantities, and at reasonable prices" [14];

- The European Union theorizes a long-term strategy for energy supply security that "must be geared to ensure, for the well-being of its citizens and the proper functioning of the economy, the uninterrupted physical availability of energy products on the market, at a price which is affordable for all consumers (private and industrial), while respecting environmental concerns and looking towards sustainable development." [15].

It seems clear that governments and other market participants priorities are geared, in the medium-long term, to security of physical supply and price affordability. These two components must be somehow balanced, considering the endowment of resources worldwide, the geographic location, and the level of economic growth, among others.

We observe that the main priority of the major importers remains the security of supply. China's Five-Year Plan for the Development of Foreign Trade sets out the goals of "sustained and steady growth of energy resources and commodity trade, and ensure the supply of domestic markets" and "supporting powerful companies" to "go global, develop overseas resources, energy, and processing and production" [16]. Korea's Energy Master Plan also emphasizes diversifying existing energy routes and expanding its domestic stockpiling capacity [17].

\subsection{Methodological Limitations}

There is not a common agreed indicator used to measure the new concept of energy security, given that it is also an evolving concept in time. In the recent research, there has been a large number of alternative proposals to assess what is really energy security. This is in part the result of a multidisciplinary interest of economists, political scientists, and environmental and energy engineers, who are all considering energy security from a different perspective and, consequently, proposing different methodologies. While the research is enriched, many analyses of energy security suffer from lack of theoretical foundations.

When proposing energy security indicators, some authors try to expand the definition of energy security, so as to legitimate a multitude of indicators. For instance, we note that [18] proposes 200 indicators grouped into 20 categories and dimensions to analyze energy security in the Asia-Pacific region. It is clear that a more stringent definition of energy security, which considers only the adequacy of energy supply and the affordability of prices, would bring about some limitation in the proliferation of indicators. However, even the simple notion of import dependency may be disaggregated in several other criteria. Is dependence measured by current or past ratios of imports to domestic consumption? How important is the diversification of specific regions or fuels? Is the balance of payments constraint relevant? These are examples of the complexity of the measurement of energy security.

An additional challenge is given by the question of the relative importance of such indicators, indices, and coefficients. Any aggregation method to present synthetic and comprehensible pictures to decision-makers is arbitrary. An interesting approach is the one used in the Index of U.S. Energy Security Risk compiled by [19]. They aggregate bottomup various categories of quantitative data to make up an aggregate index. Obviously, the weighing schemes are arbitrary, and in addition, this method forgets any qualitative aspects of energy security, such as non-tariff trade barriers, diplomatic relations, and political stability.

We also consider other problems with the measurement of energy security, aside from the problem of aggregation. Many energy security indicators are of static nature, in time 
and space, so that they cannot capture the rapid changes in energy markets, macroeconomic conditions, and international political relations.

The analysis of risk and model simulations in the field of energy security has used microeconomics and operations research methods, such as supply chain analysis, allowing for risk minimization assessments in the framework of energy imports optimization, given the risks are known and quantifiable. For instance, a model to optimize China's LNG imports, based on importing costs, exporting counterpart's risk country and shipping route risks has been developed by [20], simulating the effects of extreme events. We note that such simulations depend heavily on the subjective judgments, and consequently, the conclusions are dependent on the assumptions used to model the inputs.

A broader perspective on energy import security is given in more complex models, such as [21], who take into account also the interactions between the domestic energy systems and the international fuel markets. However, the structural complexity has a heavy cost in terms of resources required, and it is not flexible to capture short-term price fluctuations. Finally, another perspective on energy security is provided by political scientists [22,23], who consider explicitly the agents' interdependence, modeling bargaining processes and weighing the distribution of power.

We conclude the overview of traditional methodologies applied in the energy security sector, affirming that the trade-off between energy security and its associated risks is not evaluated satisfactorily. In other words, we find that there is not a clear framework to assess how price conditions and physical supply security are affected by the existing risks.

\section{Energy Security from the Exporter's Viewpoint}

\subsection{Expanding the Conventional Energy Security Framework}

As shown in the previous section, energy security has been primarily viewed from the consumer's (or importer's) perspective. The predominant body of literature on the subject has been produced in the energy-importing economies and tends to employ language that reflects this bias. Formal definitions of energy security and relevant policy documents often refer to the security of 'supply' rather than the more neutral 'energy,' and describe prices using words such as 'affordable' rather than 'fair,' 'reasonable,' or 'stable,' which would also reflect the energy producer's/exporter's interests.

The inclusion of exporters' viewpoints also allows a more comprehensive methodological approach to energy security research. Energy exporting and importing economies face many of the same challenges and threats to their energy security, primarily issues related to domestic energy systems, physical security, and logistics. However, energy exporters face a separate range of economic challenges in the context of the new world paradigms of technology changes toward decarbonization, climate change mitigation and adaptation policies, and diffusion of renewable energy sources. We identify these challenges as follows. Energy exporters are exposed to global macroeconomic fluctuations that condition their export potential. An increasing competition from new emerging producers and new technologically developed substitutes can erode the energy exporters' market share. In addition, protectionist policies and sanctions, among others, constitute a pending menace in the global fuel markets. Some of the risks can be diversified across buyers, supply channels, fuels, and geographies; however, others are systemic, as demonstrated by the COVID-19 pandemic and subsequent plunge in global oil demand.

While the physical security and stable flow of energy supplies affect both importers and exporters, their approaches to the economic component of energy security obviously differ. Energy exporters are also vulnerable to oil price shocks, such as those of 1986, 1998, and 2009, which led to a significant decrease in revenue. During such periods, energy exporters become increasingly concerned with the security of demand. This may lead to insufficient investment, particularly in the upstream sector, amplifying the magnitude of energy price cycles and their destabilizing impact on global energy markets.

Unlike their demand and import-focused counterparts, the international organizations for energy exporters do not present a clear definition of energy security in their key policy 
documents. The official OPEC statute [24] does not explicitly mention the term 'energy security' but identifies goals that reflect the underlying concept of security of demand for energy exporters: “ . . . the necessity of securing a steady income to the producing countries; an efficient, economic and regular supply of petroleum to consuming nations; and a fair return on their capital to those investing in the petroleum industry." Furthermore, various OPEC press releases on the issue emphasize "predictable demand and stable prices" and "security of demand" [25], "the reciprocal nature of energy security" [26] and "minimization of market uncertainties" [27].

The Gas Exporting Countries Forum (GECF) cites contributing to global energy security as part of the organization's mission, and it lists "supporting the security of supply and demand" among its key initiatives [28], also emphasizing "visibility of revenues," transparent "market mechanisms," and "policy actions," along with the absence of "politically motivated restrictions and unilateral decisions and interventions" as the factors that contribute to both security of supply and demand [28,29].

Among the major energy-exporting countries, Russia demonstrates the most elaborate policy approach to energy security and security of demand in particular [30]. The Russian Federation's newly adopted doctrine of energy security [31] defines energy security as the condition that ensures protection of the nation's economy and population from the national security threats in the energy domain, implying that the consumers must be supplied with fuels and energy obeying the legislation of the Russian Federation, and the export contracts and the international obligations of the Russian Federation are fulfilled. The doctrine also identifies major energy security challenges and threats. It classifies those related to foreign trade and relations into three subcategories: economic (e.g., shifts and slowdown of global economic growth, increasing the resource base, new emerging exporters, contraction of existing markets, and access to new ones), political (changes in international regulations, policy discrimination, sanctions, and transit security) and military.

Although Iran has published no policy document specifically dedicated to energy security, references to the subject can be found in a broad range of legislation and official rhetoric, including the Iranian Petroleum Act of 1987 and its amendments, the country's five-year development plans, the regulations that define the functions of the Ministry of Petroleum, and the general policies of the 'Resistance Economy' espoused by Ayatollah Khamenei [32]. These sources identify four key themes within the energy security domain. (1) Economic security relates to stable or increasing prices and energy demand, primarily in the global energy market. (2) The absence of energy sanctions focuses on monitoring existing and potential sanctions and developing mitigation plans. (3) Physical security seeks to protect energy facilities and transit routes from military and piracy attacks. (4) Environmental security primarily aims to prevent and mitigate the environmental impact of oil and gas exploration, development, extraction, and production.

Not all energy-exporting nations emphasize foreign trade in their energy security strategies. Moreover, some countries devote relatively little attention to energy security compared with other aspects of their energy policy agendas. The National Energy Security Assessment of Australia, which has not been updated since 2011, defines energy security as the "adequate, reliable and competitive supply of energy to support the functioning of the economy and social development" [33]. The document never explicitly mentions the security of demand or revenue with regard to exports. Instead, it focuses on the security of fuel imports, acknowledging that compared with electricity and natural gas, liquid fuels depend more on international supply chains and global market conditions than domestic policy decisions. Canada exhibits a similar approach to energy security. The Energy Safety and Security Act [34] focuses on domestic operational and infrastructure issues.

In Nigeria, despite the dominant share of petroleum in total exports and gross domestic product (GDP), energy security policies also prioritize domestic issues. Major policy documents, including the National Energy Policy $[35,36]$, do not articulate the concept of energy security but highlight measures that would contribute to its enhancement, including diversification of the energy mix, increasing the reliability of energy systems, building up 
domestic capacities, improving energy efficiency, and increasing research and development in the energy domain.

\subsection{Energy Security Challenges for Exporters}

The review of the energy security policies of producing (exporting) countries suggests that the two major categories of energy security threats-physical supply disruption (such as armed conflict, piracy, terrorism, expropriation, and natural disasters) and economic (volume and price) instability-apply to both importers and exporters. However, exporters face a distinct set of challenges that require specific risk mitigation strategies. These include:

- Negative macroeconomic dynamics (globally, and in importing economies)

- Slowing demand for energy and specific fuels (globally, and in importing economies)

- $\quad$ Downside price fluctuations in the global markets

- Increasing competition, including from new exporters

- $\quad$ Buyer-related risks including breach of contract and default

- $\quad$ Protectionism, including tariff and non-tariff market access barriers

- Sanctions, ranging from export embargoes to technological, financial, investment, and other collaboration restrictions

- $\quad$ Shifts in legislation in energy importing markets

These risks can be further classified by fuel type and geography. The potential geographic breakdown can distinguish between domestic and international markets (by individual country or combinations of countries/regions), as well as transit areas. Such classification can inform prevention and mitigation strategies by differentiating between diversifiable and non-diversifiable (systemic) risks.

\subsection{Measuring Energy Security}

Most energy security indicators apply to both energy importing and exporting countries. These "universal" indicators generally measure the quality or status of a domestic energy system, such as its reliability, resilience, availability, and diversity of resources, investment flows, and environmental impacts [37-39]. However, in the areas related to foreign trade, indicators and their interpretation differ significantly between energy importers and exporters; these can be broadly divided into three categories: dependency, markets and supply chains, and trade strategies.

A country's energy trade balance is a primary indicator and source of data for dependency, which is often expressed in physical units such as barrels of oil or tonnes of oil equivalent. Net energy exports generally imply a certain self-sufficiency level-one of the most basic conventional energy security indicators [40]. However, in the case of energy, exporters' dependency can also be interpreted as the level of exposure of the energy sector to international markets. Moreover, despite overall net energy exports, a country may have net dependency for particular fuels. Table 1 compares aggregated net energy exports with energy production and total final energy consumption (TFEC) for the Gulf Cooperation Council (GCC) states.

The indicators measuring the economic dependency (and potential vulnerability) of an energy-exporting nation generally compare the export values for energy (or a particular fuel) with major macroeconomic indicators. Dike [41] suggests total exports and GDP as the key measurements (see Table 2 for the corresponding estimates for the GCC countries). 
Table 1. Relative share of net energy exports to energy production and TFEC for GCC countries, 2017.

\begin{tabular}{|c|c|c|c|c|c|}
\hline & $\begin{array}{c}\text { Energy } \\
\text { Production, } \\
\text { MTOE }\end{array}$ & $\begin{array}{c}\text { Total Final } \\
\text { Consumption } \\
\text { MTOE }\end{array}$ & Total EXP, MTOE & $\begin{array}{c}\text { EXP/Energy } \\
\text { Production, \% }\end{array}$ & EXP/TFEC, \% \\
\hline Bahrain & 22.4 & 6.3 & 8.3 & $37 \%$ & $132 \%$ \\
\hline Kuwait & 162.2 & 19.3 & 128.3 & $79 \%$ & $665 \%$ \\
\hline Oman & 77.9 & 21.3 & 50.1 & $64 \%$ & $235 \%$ \\
\hline Qatar & 225.2 & 18.3 & 179.5 & $80 \%$ & $981 \%$ \\
\hline Saudi Arabia & 646.8 & 140.7 & 425.4 & $66 \%$ & $302 \%$ \\
\hline UAE & 229.4 & 62.3 & 136.9 & $60 \%$ & $220 \%$ \\
\hline
\end{tabular}

EXP $=$ net exports; TFEC $=$ total final energy consumption. Source: own elaboration on data of [42].

Table 2. Contribution of exports of mineral fuels * to total exports and GDP for GCC countries.

\begin{tabular}{ccccccccccc}
\hline Country & $\begin{array}{c}\text { Exports of Mineral } \\
\text { Fuels, } \\
\text { \$Million }\end{array}$ & \multicolumn{2}{c}{$\begin{array}{c}\text { Total Exports, } \\
\text { \$ Million }\end{array}$} & GDP, \$ Million & \multicolumn{2}{c}{$\begin{array}{c}\text { Exports of Mineral } \\
\text { Fuels/Total } \\
\text { Exports, } \%\end{array}$} & $\begin{array}{c}\text { Exports of Mineral } \\
\text { Fuels/GDP, } \%\end{array}$ \\
\hline & 2017 & 2018 & 2017 & 2018 & 2017 & 2018 & 2017 & 2018 & 2017 & 2018 \\
\hline Bahrain & 5564 & 6921 & 11,088 & 12,979 & 35,305 & 37,740 & $50 \%$ & $53 \%$ & $16 \%$ & $18 \%$ \\
\hline Kuwait & 49,573 & 65,391 & 52,977 & 71,941 & 120,449 & 139,742 & $94 \%$ & $91 \%$ & $41 \%$ & $47 \%$ \\
\hline Oman & 18,655 & 27,323 & 32,404 & 43,281 & 70,577 & 79,253 & $58 \%$ & $63 \%$ & $26 \%$ & $34 \%$ \\
\hline Qatar & 54,351 & 72,509 & 63,968 & 81,571 & 166,929 & 192,009 & $85 \%$ & $89 \%$ & $33 \%$ & $38 \%$ \\
\hline $\begin{array}{c}\text { Saudi } \\
\text { Arabia }\end{array}$ & 170,245 & 231,587 & 213,210 & 285,847 & 686,549 & 779,167 & $80 \%$ & $81 \%$ & $25 \%$ & $30 \%$ \\
\hline UAE & 69,182 & 92,538 & 313,510 & 316,860 & 377,701 & 414,179 & $22 \%$ & $29 \%$ & $18 \%$ & $22 \%$ \\
\hline
\end{tabular}

* Classified under HS Code line 27. Sources: own elaboration on data of [43-45].

However, one can also estimate the impact of energy exports on a country's trade balance, current account, and total sales (or value added) of the energy sector. In the energy security literature, the conventional approach for energy importers to assess the risk profiles of suppliers involves using a variety of measurements and indicators. Similarly, energy exporters can develop risk assessment toolkits for existing and potential markets or specific buyers that evaluate political and economic risk indices, bilateral trade and payment history, current and potential trade barriers, other protectionist measures, and domestic policies that would impact energy exports. The risk factors for specific energy export routes and modes (e.g., maritime shipments, pipelines, and railways) can also be quantified and combined with consumer risk profiles for a comprehensive energy security analysis of export supply chains (see $[46,47]$ for such approaches from the importers' perspective).

The other group of energy demand security indicators focuses on a country's export portfolio and strategies. The Herfindahl-Hirschman Index (HHI) is a common measure of market concentration used to determine market competitiveness and can be used to analyze the diversification of energy exports $[48,49]$. Figure 1 shows the historical trends in $\mathrm{HHI}$ index for the five GCC countries. In this case, HHI was calculated by squaring the market share of every oil importer from each of the GCC countries in focus and then summing the resulting numbers. According to [50], HHI measurements below 1500 indicate a competitive market, measurements from 1500 to 2500 indicate a moderately concentrated market, and measurements above 2500 indicate a highly concentrated market. 


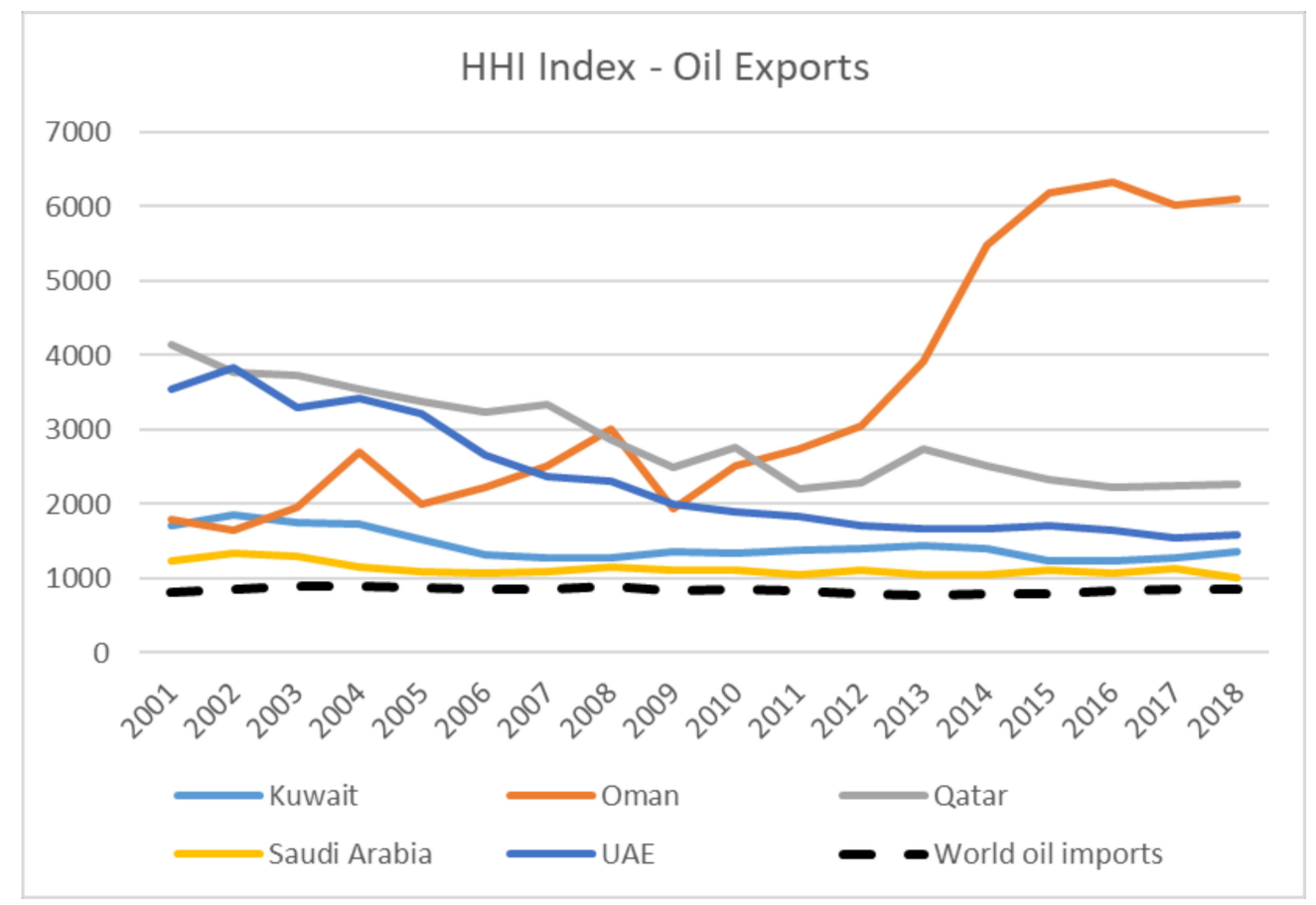

Figure 1. HHI oil export indices for GCC countries. Source: own elaboration on data of [44].

In the case of the major exporters, the index is slightly decreasing in the range of moderate concentration at the end of period, with the exception of Oman. This pattern suggests that there has been a diversification of the energy export portfolio of the oil exporters considered (except Oman), which generally should bring an improvement in the risk profile. However, it may also increase costs due to the higher overhead associated with managing additional consumers/markets and reduce the share of more profitable existing consumers. The portfolio theory approach can be used to estimate the efficient risk-reward frontiers for the exporter's portfolios. This is tantamount to measure the two contrasting elements of the notion of demand security for the energy exporter, namely, increasing export volumes and increasing export prices. The next section will discuss this methodology in greater detail.

\subsection{Policy Tools}

As far as the policy tools used by energy exporters to enhance their energy security are concerned, we find that domestic market policies greatly affect the export capacity and competitiveness of an energy exporter. A country's regulatory and policy environment can incentivize companies to engage in exploration and production activities [51,52], which increase the supply of energy available for export. Authorities can achieve a similar impact by curbing domestic demand through energy efficiency standards and other demand management measures [53,54]. Policymakers must also ensure sufficient investment in upstream and midstream infrastructure to maximize the potential of energy exports, including through public-private partnerships, and safeguard their physical security $[55,56]$. Finally, maintaining a certain level of fuel stocks and managing spare production capacity can help alleviate fluctuations in demand and allow an exporter to quickly adjust to the current state of the market, although such measures carry additional costs [57].

Taxation provides another key policy lever for the entire energy export value chain, from exploration and production to transportation, refining, storage, and exports [58,59]. This includes tax regulations in downstream and adjacent industries, which have an indirect impact on energy exporters. An effective tax regime for the energy industry requires authorities to balance the competitiveness of domestic and international markets on the one hand and fiscal revenues and risk of counteractions from trading partners and 
foreign competitors on the other. Regardless of tax levels, the stability of the regulatory environment is essential for the long-term planning, investment, and overall development of the energy-exporting industry.

Domestic energy price incentives distort demand and reduce the availability of energy supplies for the export market $[60,61]$. This not only decreases export revenue but also can depress investment in energy production and throughout the energy export value chain. Conversely, if domestic prices follow the global market, increased domestic demand generally benefits producers by offering additional revenue in the local market, presumably with lower risks than associated with exports.

In the foreign trade domain, diversification remains a central risk mitigation strategy for importers and exporters alike [62,63]. Energy exporters can diversify their exports in several ways. The diversification of buyers (markets) can help reduce counterparty concentration risks and avoid excessive dependence on a given market. This is often combined with the diversification of transit routes and modes in order to avoid or reduce exposure to individual logistical chokepoints and transit nodes. Finally, diversification across fuel types and products further increases the stability of export revenues by reducing the potential impact of systemic risks (that cannot be diversified across consumers) associated with a particular global commodity market.

Hedging is another tool to enhance energy security for the global energy market participants $[64,65]$. Energy exporters typically determine their hedging strategies based on their export contract terms. They can choose from a range of options for both shipping and payment arrangements, depending on their strategies for specific markets, risk tolerance, and targeted energy export portfolio parameters. Supply arrangements vary from structured long-term contracts to spot sales and can specify total volume or detailed shipping schedules. Additional clauses that can benefit exporters include 'take-or-pay' and 'no re-sell' agreements. Pricing terms also vary significantly, from fixed prices for the duration of a contract to variable schemes that link the prices of individual shipments to commodity benchmarks, indices, or hub prices, with a variety of hybrid pricing systems in between. Exporters may also opt for 'cost, insurance and freight' (CIF) pricing, which captures logistics margins and the associated risks, in lieu of more conventional 'free-on-board' (FOB) arrangements, in which they deliver shipments at their own borders. However, factors outside the control of energy exporters can limit their ability to effectively manage risks through the terms of their export contracts.

These include global and regional energy market trends, the dynamics of bilateral relations, and the bargaining power of buyers and transit countries. In turn, these variables largely depend on the specifications of exported fuels (e.g., the market conditions may significantly differ for light and heavy crudes), the geographic locations of export nodes, and availability of shipping modes and routes.

Vertical integration across global energy value chains can also enhance the energy security of exporters [66,67]. Acquiring midstream and downstream energy assets (or stakes in them) in foreign markets can give an investor control over fuel supply management, increasing the security and predictability of foreign demand for energy produced in the domestic market. Greater control over such assets can also enable price management across the value chain, including transfer pricing. In addition, this strategy can alleviate existing or potential market access barriers in key target markets. The resulting physical presence in key energy trading hubs also increases the flexibility and scope of operations (spot trading, swaps, etc.), further diversifying the revenue streams. The penetration of Saudi Aramco into its key target markets provides a good example of the vertical integration strategy. The company has established its presence-primarily through joint ventures-in the refining and logistics sectors of Europe, the U.S., Southeast Asia, and across the major East Asian markets. However, its attempts to gain control over midstream and downstream energy assets can be perceived as an energy security (or even national security) threat by energy-importing countries. Asset swaps, in which the importers gain control over foreign energy upstream assets in return for a stake in their midstream and downstream 
operations, can mitigate such concerns. The EU denied the attempts of Russia's natural gas exporter Gazprom to bid for regional distribution companies in the EU; however, the company managed to conclude a deal swapping its natural gas and condensate production assets for the trading and storage business in Germany and Austria of the German based company BASF (Ludwigshafen, Germany).

In conclusion, diversification can become costly. The management of operations across additional markets and shipping routes requires extra resources and sometimes reduces the share of the most profitable or efficient ones. The optimal diversification level should be defined by the exporter's perception of risks associated with particular buyers, supply routes, and global energy markets; the portfolio approach presented in the next section provides a method for this assessment.

\section{Portfolio Optimization of Energy Exports}

\subsection{Portfolio Optimization in the Energy Domain}

The conceptual formulation of the portfolio model was first introduced by [68] and has since been extensively applied in financial analysis and other fields. The theoretical framework consists of the minimization of a portfolio risk (i.e., the variance) for a given level of expected return. The mirror concept consists, obviously, of the maximization of the expected return for a given level of risk.

One of the first applications of portfolio theory in the energy sector was related to the optimization of the procurement process by the utilities in the U.S. back in the 1970s [69]. Later, the scope expanded to include the optimization of energy consumption [70] and other performance metrics [71] on the national scale, as well as the assessment of individual projects and investment decisions [72,73], including the focus on particular customer groups [74]. Matching the classic portfolio theory studies in the field of finance, the risk in the energy optimization problems is generally represented by the portfolio variance. However, the optimization parameters vary from fuel input costs and investment outcomes to non-financial targets such as capacity or emissions.

Recent studies in the energy field have applied a number of methodological innovations supplementing the classic portfolio optimization approach. These include the decomposition hybrid interval prediction method [75], multi-objective (value-at-risk and conditional value-at-risk) risk optimization [76] and encompassing the forecast error as part of the risk asset [77]. However, despite the expanding scope and methodological progress, the application of portfolio optimization in the energy sector remains primarily focused on the domestic issues, with limited coverage of the energy trade and energy security areas.

As shown in the previous section, energy security has been primarily viewed from the importer's perspective. A similar trend can be observed in the studies that apply a portfolio optimization method to this problem. Methodologically, these studies define risks as either the fluctuation in import costs [78-80] or the supplier's economic and political state [81,82]. The latter, index-based approach is also used in the rare exporter-focused study of Iranian gas exports [83]. Note that when the indices that characterize energy importers or exporters are used as a proxy for supply security or price risks, the method becomes susceptible to the drawbacks typical for energy security coefficients highlighted in the previous chapter.

The case study developed in this article attempts to address these gaps in the scope and method of the previous literature. We use the optimal portfolio theory approach to evaluate the notion of security for energy exporters, considering two facets: physical supply security and price security.

\subsection{Methods and Data}

This paper explores the growth-volatility and price-volatility dynamics of oil export portfolio structures for five GCC economies: Kuwait, Oman, Qatar, Saudi Arabia, and the UAE. (We exclude Bahrain, whose current oil export structure does not permit construction of an efficient frontier portfolio). This approach provides an innovative assessment tool for 
the two major pillars of energy security—security of demand and price optimization-from the exporter's perspective. It can be applied to assess the current composition of the energy export portfolios, test the potential impacts of market development scenarios, and help inform relevant response (prevention) strategies.

A country's energy exports generally comprise a set of flows to different buyers that vary in volume, growth rate, and price terms. These can be represented as a portfolio, in which the total export volume growth rate (or export price) equals the weighted sum of the relevant values associated with specific buyers, and where these total portfolio characteristics are subject to a diversification effect. In this case, the return is represented by the export growth rate (or export price) and uncertainty as to the underlying volatility of the return variables. Under these assumptions, energy exporters will strive to maximize their expected portfolio returns for a given level of risk or, conversely, minimize the risks associated with a certain level of expected returns.

We assess the trade-offs facing oil exporters, constructing two efficient portfolio frontiers for the five countries in focus with the following characteristics. (i) The oil export volume growth portfolio is characterized by a return. We assume that this is measured by the monthly growth rate of oil export volumes. In addition, there is a variance associated with the structural composition of the portfolio; we assume that this is measured by the historical export data for individual buyers. The portfolio composition shows the trade-off between a higher growth of exports and concentration of customer countries, while a lower risk is associated with a higher diversification of customer countries. (ii) The oil export price portfolio is characterized by a return, reflecting the average monthly price received by the exporter. The variance of the portfolio is estimated based on the price fluctuations paid by the individual customer countries, which is weighted by their shares of importance in the total oil exports of each exporter. The portfolio shows different combinations of high expected return with high concentration on a few best buyers and low expected return with a more diversified composition of buyers. These portfolios cover the two primary aspects of energy security from the exporter's perspective: minimize the risk while securing demand and obtaining favorable price terms.

In detail, the theoretical specification is as follows. Based on the standard portfolio theory, we assume that agents minimize the variance of the portfolio for a given level of expected return [11]. As explained above, we consider in the first case the return as measured by the monthly growth rate in oil export volumes. The variance of the portfolio is the sample variance of the weighted growth rates of exports to individual buyers. In the second case, the return variable reflects the average monthly oil price recorded by an exporter. Thus, the portfolio variance is the variance of the weighted prices paid by individual buyers.

We consider that from the viewpoint of the exporter $\mathrm{j}$, there is a world demand for oil export $f_{j}(\cdot)$, which is the optimal oil demand for exporter $j$ :

$$
E_{j}=f_{j}\left(G D P_{\text {world }}\right) \text {. }
$$

The desired or optimal level of oil demand implies a desired growth rate of energy export to be satisfied with an export portfolio $\mathrm{g}(\cdot)$ to different $\mathrm{n}$ customer countries:

$$
E_{j}=g_{j}\left(E_{j 1}, E_{j 2}, \ldots, E_{j n}\right) .
$$

Therefore, the return is the overall export growth rate, which is computed as the monthly growth rate of oil export volumes to $\mathrm{n}$ suppliers (country subscript omitted for simplicity):

$$
\theta^{*}=\left(\mathrm{E}_{\mathrm{t}}-\mathrm{E}_{\mathrm{t}-1}\right) / \mathrm{E}_{\mathrm{t}-1}=\Sigma_{\mathrm{i}=1, \mathrm{n}} \mathrm{s}_{\mathrm{i}}\left[\left(\mathrm{E}_{\mathrm{i}, \mathrm{t}}-\mathrm{E}_{\mathrm{i}, \mathrm{t}-1}\right) / \mathrm{E}_{\mathrm{i}, \mathrm{t}-1}\right]
$$

and the uncertainty is the variability of the export growth rate across suppliers:

$$
\sigma=\operatorname{Var}\left(\theta_{1}, \theta_{2}, \ldots, \theta_{\mathrm{n}}\right) \text {. }
$$


In the second case, we consider that maximizing the return of the export portfolio implies a benefit for the exporting country that is the price benefit associated with the oil exports:

$$
\begin{gathered}
\mathrm{p}_{\mathrm{b}}=\mathrm{p}^{*}, \\
\mathrm{p}^{*}=\mathrm{h}^{*}\left(\mathrm{p}_{1}, \mathrm{p}_{2}, \ldots, \mathrm{p}_{\mathrm{n}}\right) .
\end{gathered}
$$

We measure the return of this benefit $\mathrm{p}_{\mathrm{b}}$ as the average oil export price attained in the world market. This is a function of the export composition of the different $\mathrm{n}$ prices charged the $\mathrm{n}$ customer countries.

For each exporter, the standard portfolio optimization theory prescribes to minimize the weighted average of the elements of the covariance matrix:

$$
\mathrm{v}=\sum_{\mathrm{i}} \sum_{\mathrm{j}} \mathrm{s}_{\mathrm{i}} \mathrm{s}_{\mathrm{j}} \mathrm{v}_{\mathrm{ij}}
$$

where $\mathrm{v}$ is the square root of the return's covariance matrix and $\mathrm{s}_{\mathrm{i}}$ is the $\mathrm{i}$-th export shares, given the constraint of the optimal total return rate of i-th economy $\Theta_{i}^{*}$, which can be viewed as the sum of the returns weighted by each customer's relative importance:

$$
\Theta_{\mathrm{i}}^{*}=\sum_{\mathrm{j}} \mathrm{s}_{\mathrm{j}} \Theta_{\mathrm{j}}^{*} .
$$

This gives the relation between the minimum variance and its return for different values of the constraint, which is the efficient frontier for empirical estimation, as a relation of the standard deviation with the return and return squared, which is expressed as follows:

$$
\mathrm{SD}_{\mathrm{t}}=\mathrm{a}+\mathrm{b}_{1} \Theta_{\mathrm{t}}+\mathrm{b}_{2} \Theta_{\mathrm{t}}^{2}+\mathrm{e}_{\mathrm{t}} .
$$

We can consider $\mathrm{SD}_{\mathrm{t}}$ as the standard deviation of the i-th oil export flows or of the i-th price benefit, while a is the fixed effect, $\Theta_{t}$ as the annual growth rate of the total oil quantity flow or of the average profitability index, the coefficients $b_{1}$ and $b_{2}$ define the frontier convexity, and $e_{t}$ captures the residual error.

In the space mean-standard deviation, it is possible to show that Equation (9) defines the upper arm of a parabolic function of efficient portfolios, which constitutes the portfolios frontier characterized by the minimum variance associated to a given return.

The dataset used in this study comprises monthly volumes and prices of crude oil exports disaggregated by destination country for each of the five major oil exporters from the GCC region: Kuwait, Oman, Qatar, Saudi Arabia, and the UAE. The data availability for Bahrain oil exports shows an erratic pattern to a narrow range of buyers. Thus, there is an insufficient history of oil exports data that does not allow applying the portfolio analysis approach. Therefore, we leave Bahrain out of the scope of this study. However, the GCC countries neither publicly release direct exports data nor make it available to opensource data platforms, such as those provided by the World Bank or International Trade Centre $[43,44]$. Therefore, we used these sources to obtain the 'mirror' exports data, i.e., the monthly volumes and prices of crude oil imported from each of the GCC countries by every other economy in the world. These datasets for oil importing countries are publicly available at $[43,44]$.

To determine a proxy for the price at the exporter's border, we subtracted the estimated shipping costs (calculated on a per unit, monthly basis for all major oil export routes from the GCC ports) from the corresponding price recorded at the importer's border. We note that the model captures short-term effects, as the portfolios are estimated using monthly exports data. Risk assessment in this study is also limited to the specific risks associated with a particular route from the exports to the customer country that can be diversified. It does not include systemic risks (such as the COVID-19 pandemic) that can destabilize an entire industry, market, or the entire global economy. Regarding the issue of seasonality, the existing literature suggests that it exists in the futures market for gas [84] but is arguably negligible for oil [85]. Therefore, it is not considered in this study. 
The variable of oil exports in physical terms is measured with the monthly growth rates of exports and its associated standard deviations across the portfolio of buyers. The variable of price benefit in dollar terms is measured using as proxy the FOB price associated with each buyer in US $\$ 1000$ per tonne.

The data are aggregated for each exporting country studied for the period $\mathrm{T}=(2008: 1-$ 2018:12) for a total of 132 monthly observations and a specific number of buyers. We preliminary noted that for each GGC exporter, the datasets contained a number of buyers that report very small amounts with an intermittent frequency. These are occasional flows for only one or a few periods, accounting for less than $1 \%$ of the total export flows. We decided to exclude these small occasional buyers, and therefore, we consider the set of buyers that constitute $99 \%$ of the total exports. The number of buyers $\mathrm{M}$ considered for each country is $\mathrm{M}_{99 \%, \text { Kuwait }}=11, \mathrm{M}_{99 \%, \text { Oman }}=4, \mathrm{M}_{99 \%, \text { Qatar }}=4, \mathrm{M}_{99 \%, \text { SaudiArabia }}=24$, and $\mathrm{M}_{99 \%, \mathrm{UAE}}=13$.

To estimate Equation (9), we analyze the properties of cointegration of the series. The Dickey-Fuller test shows that all series, as expected, have a unit root. We also perform the Engle-Granger tests (results are reported in Table 3). These tests are all showing that there exists cointegration, allowing estimation of the equation avoiding spurious correlation.

Table 3. Cointegration analysis.

\begin{tabular}{|c|c|c|c|c|c|}
\hline \multicolumn{6}{|c|}{ Kuwait } \\
\hline \multicolumn{3}{|c|}{ Oil export growth rate } & \multicolumn{3}{|c|}{ Oil export price } \\
\hline \multicolumn{2}{|c|}{ Engle-Granger test } & \multicolumn{4}{|c|}{ Engle-Granger test } \\
\hline TestStat & $p$-value & Number of lags & TestStat & $p$-value & Number of lags \\
\hline-4.08 & 0.05 & 3 & -3.94 & 0.076 & 2 \\
\hline \multicolumn{6}{|c|}{ Oman } \\
\hline \multicolumn{3}{|c|}{ Oil export growth rate } & \multicolumn{3}{|c|}{ Oil export price } \\
\hline \multicolumn{2}{|c|}{ Engle-Granger test } & \multicolumn{4}{|c|}{ Engle-Granger test } \\
\hline TestStat & $p$-value & Number of lags & TestStat & $p$-value & Number of lags \\
\hline-7.26 & 0.0000 & 2 & -5.24 & 0.005 & 2 \\
\hline \multicolumn{6}{|c|}{ Qatar } \\
\hline \multicolumn{3}{|c|}{ Oil export growth rate } & \multicolumn{3}{|c|}{ Oil export price } \\
\hline \multicolumn{2}{|c|}{ Engle-Granger test } & \multicolumn{4}{|c|}{ Engle-Granger test } \\
\hline TestStat & $p$-value & Number of lags & TestStat & $p$-value & Number of lags \\
\hline-4.04 & 0.06 & 5 & -6.24 & 0.000021 & 2 \\
\hline \multicolumn{6}{|c|}{ Saudi Arabia } \\
\hline \multicolumn{3}{|c|}{ Oil export growth rate } & \multicolumn{3}{|c|}{ Oil export price } \\
\hline \multicolumn{2}{|c|}{ Engle-Granger test } & \multicolumn{4}{|c|}{ Engle-Granger test } \\
\hline TestStat & $p$-value & Number of lags & TestStat & $p$-value & Number of lags \\
\hline-5.42863 & 0.0005 & 7 & -5.14 & 0.0017 & 10 \\
\hline \multicolumn{6}{|c|}{ UAE } \\
\hline \multicolumn{3}{|c|}{ Oil export growth rate } & \multicolumn{3}{|c|}{ Oil export price } \\
\hline \multicolumn{2}{|c|}{ Engle-Granger test } & \multicolumn{4}{|c|}{ Engle-Granger test } \\
\hline TestStat & $p$-value & Number of lags & TestStat & $p$-value & Number of lags \\
\hline-3.53 & 0.18 & 5 & -6.24 & 0.00012 & 2 \\
\hline
\end{tabular}

The results of the estimation of Equation (9) for the two variables for the five countries are reported in Table 4 , reporting the values and signs of the estimated coefficients $b_{1}$ and 
$b_{2}$. All estimates are generally significant, and the estimated values confirm the theory, namely, $b_{1}$ is negative and $b_{2}$ is positive, so that the frontier curvature is convex in the mean-return space. The sample period is 132 observations for all the quantity equations, while it is slightly lower for the price equations, as some outliers due to poor data quality have been eliminated from the estimation sample (as reported in Table 4). Note that the coefficient $b_{2}$ greater than one indicates increasing diversification and vice versa. The empirical results show that diversification is decreasing for all countries.

Table 4. Estimation results.

\begin{tabular}{|c|c|c|c|c|c|}
\hline \multicolumn{6}{|c|}{ Oil Export Growth Rate } \\
\hline Coeff & Saudi A. & Kuwait & UAE & Oman & Qatar \\
\hline Const & 0 & $0.02 * *$ & 0 & $-0.6^{* *}$ & 0 \\
\hline B1 & $-0.046^{* *}$ & $-0.027^{* *}$ & $-0.07^{* *}$ & $-0.51^{* *}$ & $-0.11^{* *}$ \\
\hline B2 & $0.045^{* *}$ & $0.045^{* *}$ & $0.062 * *$ & $0.31^{* *}$ & $0.10^{* *}$ \\
\hline N. obs & 132 & 132 & 132 & 132 & 132 \\
\hline R-squared & 0.74 & 0.92 & 0.58 & 0.33 & 0.76 \\
\hline $\begin{array}{c}\text { Schwarz } \\
\text { B.I.C. }\end{array}$ & -623.2 & -501.4 & -499 & -144.7 & -413.7 \\
\hline $\begin{array}{c}\text { Log } \\
\text { likelihood }\end{array}$ & 628.2 & 508.8 & 503.9 & 152 & 418 \\
\hline \multicolumn{6}{|c|}{ Oil Price Benefit } \\
\hline Coeff & Saudi A. & Kuwait & UAE & Oman & Qatar \\
\hline Const & $50.7^{* *}$ & 3.1 & $62.2 * *$ & $126.9^{* *}$ & 0 \\
\hline B1 & $-0.08^{* *}$ & -1.5 & -0.115 & -0.176 & $-0.09^{* *}$ \\
\hline B2 & $0.044 *$ & 1.8 & $0.001^{* *}$ & 0.0002 * & $0.0001 *$ \\
\hline $\mathrm{N}$ obs & 121 & 125 & 124 & 113 & 119 \\
\hline R-squared & 0.27 & 0.02 & 0.08 & 0.21 & 0.93 \\
\hline $\begin{array}{l}\text { Schwarz } \\
\text { B.I.C. }\end{array}$ & 490.2 & 545 & 563.6 & 557.2 & 383.9 \\
\hline $\begin{array}{c}\text { Log } \\
\text { likelihood }\end{array}$ & -478.2 & -537.8 & -556.4 & -550.1 & -379.1 \\
\hline
\end{tabular}

Notes: ${ }^{* *} 1 \%$ significance; ${ }^{*} 5 \%$ significance. Schwarz B.I.C.: Schwarz's Bayesian information criteria.

\subsection{Scenario Design}

We develop several scenarios to assess the potential impacts on the above portfolios from changes in portfolio composition, demand shocks, and shifts in global oil shipment patterns, to test how the oil export portfolios of the five GCC countries perform under various demand and logistics shocks.

First, we establish a baseline scenario-Baseline 2018-by identifying the positions on the countries' efficient frontier curves that correspond to their respective average monthly oil exports data for 2018. Then, we test the short-term impacts of a sharp increase in Chinese oil imports and subsequently assess the longer-term consequences of potential redistribution of global oil import flows by reducing the shares of the U.S. in the export portfolios of the five countries and redistributing this among the other importers. Finally, we test the resilience of the portfolios to a logistics shock caused by a blockade of the Malacca Strait. Table 5 summarizes the scenario inputs. 
Table 5. Energy security scenarios for oil exports portfolios.

\begin{tabular}{cl}
\hline \multicolumn{1}{c}{ Scenario } & \multicolumn{1}{c}{ Description } \\
\hline Baseline 2018 & $\begin{array}{l}\text { For the five oil exporters-Kuwait, Oman, Qatar, Saudi } \\
\text { Arabia, and the UAE-we estimate the optimal points on } \\
\text { their efficient frontier curves, corresponding to the 2018 } \\
\text { observed average monthly growth rates of oil export } \\
\text { volumes and export prices. }\end{array}$ \\
\hline Increased Chinese demand & $\begin{array}{l}\text { We increase the oil export volumes to China by 20\% } \\
\text { compared to Baseline 2018 for each exporter. The exports to } \\
\text { other markets remain unaffected. }\end{array}$ \\
\hline Exports redistribution & $\begin{array}{l}\text { We reduce the share of the US imports by 20\% compared to } \\
\text { Baseline 2018 for each exporter. Then, the reduced volumes } \\
\text { are redistributed among the other buyers in proportion to } \\
\text { their shares observed under the Baseline 2018 scenario. }\end{array}$ \\
\hline Malacca Strait blockade & $\begin{array}{l}\text { We assume that the Malacca Strait is blocked, and it takes oil } \\
\text { cargoes an additional 3.5 days to reach the East Asian } \\
\text { markets. This leads to a 20\% reduction in exports volumes } \\
\text { to the region. The other markets remain unaffected. }\end{array}$ \\
\hline
\end{tabular}

\section{Results and Discussion}

\subsection{Efficient Frontiers of Oil Exports}

Empirical estimations allow us to construct the relevant arm of the efficient frontier, given by Equation (9), which represents a quadratic relation between the standard deviation of the growth rates (the risk measure) and average growth (the return measure). In other words, this makes risk an increasing function of return: the higher the growth rate of the target variable, the higher the associated dispersion of the portfolio composition, which means higher risk. We show the efficient frontiers for growth of crude oil export volumes in Figure 2a. Note that in Figure 2a, the unit of the vertical axis is the monthly growth factor (i.e., $1+$ growth rate). The values shown are the fitted values based on the estimated coefficients of Equation (9) for each country, as given in Table 4. This shows the estimated trade-off between the exports growth rate and its associated risk (standard deviation of exports growth rate). The black dots on the chart represent the average monthly oil export growth recorded in 2018, which serves as the baseline for scenario analysis. For instance, the return-risk combination for Saudi Arabia gives an average growth rate for oil exports of 1.05 and a standard deviation of 0.047 .

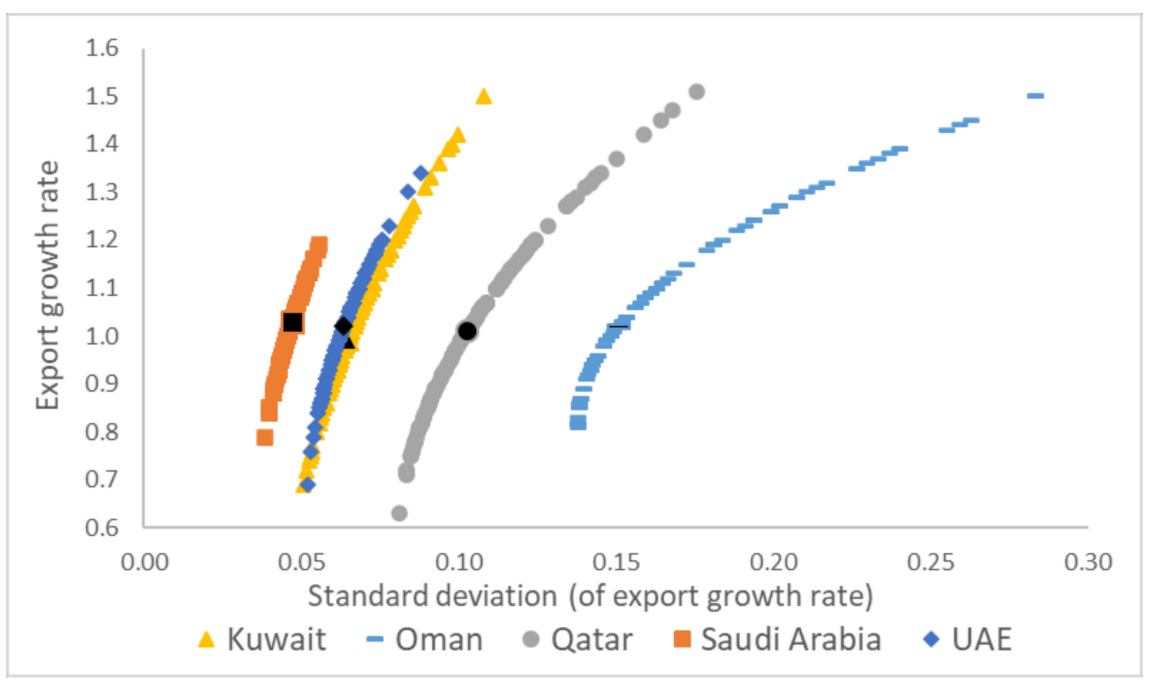

(a)

Figure 2. Cont. 


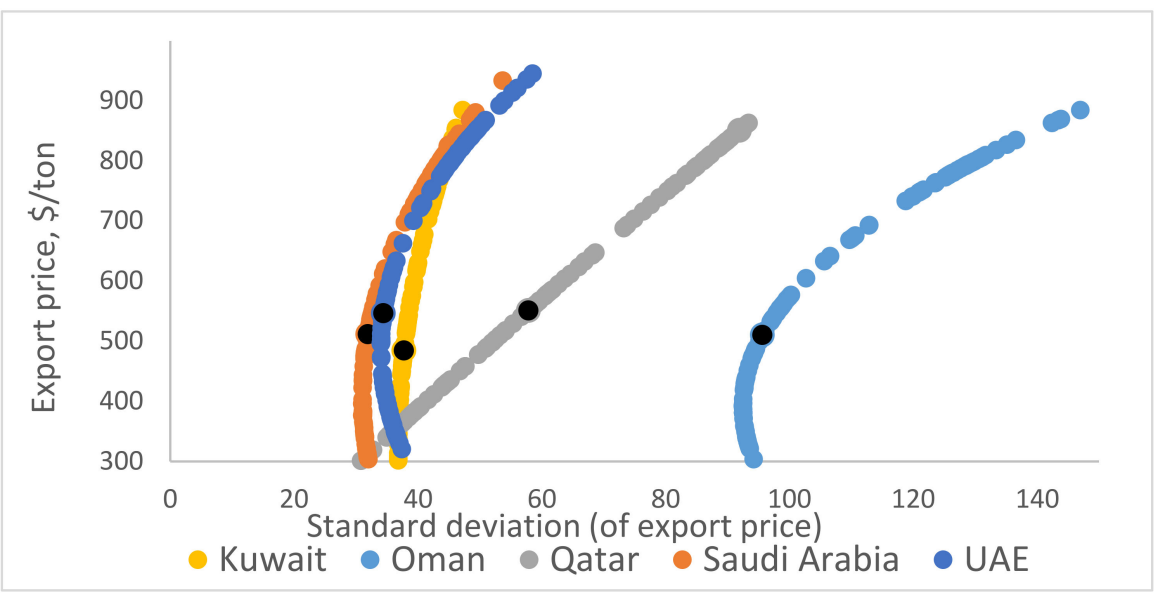

(b)

Figure 2. (a): Efficient oil export frontiers: export growth rate. (b): Efficient oil export frontiers: export price. Note: Black dots represent average monthly values observed in 2018.

Considering the return-risk combination for the countries analyzed, note that the 2018 average monthly growth rates for the five countries fall within a narrow range: from 0.992 for Kuwait to 1.023 for Oman. However, the volatility of oil export growth in any given month varies substantially: the monthly changes in exported oil volumes can exceed $20 \%$. This explains the shape of the efficient frontier curves, which-with the exception of Saudi Arabia's-apply even in cases of $+/-30 \%$ monthly growth fluctuations.

We observe a broader range of standard deviations for 2018 export growth. Saudi Arabia (0.047) exhibits the least volatility, which is followed by Kuwait $(0.062)$ and the UAE (0.064), while Qatar (0.1) and Oman (0.15) show much higher levels. Thus, despite their similar export growth rates, the countries demonstrate a wide variance in risk levels, which can be explained by differences in the composition of their export portfolios. Based on the risk profiles represented by the efficient frontier curves, we can identify three groups of oil exporters with similar characteristics.

Saudi Arabia holds the lowest risk oil export portfolio of the five countries. The Kingdom's steep efficient frontier curve suggests that it can increase oil exports without significantly raising its portfolio risk level, which is a strong position that results from the country's production profile and market strategies. Saudi Arabia is by far the largest oil exporter in the GCC, exceeding the second biggest—-the UAE—by almost threefold. Its export growth over the total observation period has also been relatively smooth, on average $0.3 \%$ per month. Despite the Kingdom's significant spare capacity margins and historical role as the 'swing producer' to balance global markets, monthly fluctuations in its oil export volumes rarely reach $10 \%$. Saudi Arabia also has the most diversified oil export portfolio in the GCC, with a 2018 HHI score of 1015-well below the 1500 competitive market threshold. Furthermore, Saudi Arabia has established a strong downstream presenceprimarily through joint ventures-in key target markets across the globe.

Kuwait and the UAE have similar efficient oil export frontiers. The two countries demonstrate similar historical patterns of oil export growth: a sharp increase until 2012-2013, followed by a plateau with average monthly export volumes of 10.2 million tonnes for the UAE and 8.2 tonnes for Kuwait. They each export more than twice as much oil as Qatar or Oman, though far less than Saudi Arabia. Both Kuwait and the UAE have relatively diversified export portfolios, with $2018 \mathrm{HHI}$ values of 1357 and 1584, respectively. In the case of Kuwait, its lower HHI compensates for the volatility associated with higher average monthly exports growth $(1.9 \%$ over the observed period) and monthly exports fluctuations that often reach double digits. The UAE has a more concentrated export portfolio due to the large share taken up by Japan, which accounts for over $30 \%$ of its oil 
exports. However, the UAE has recorded more modest export growth than Kuwait, $0.8 \%$ monthly on average, with a lower magnitude of monthly fluctuations.

The Kuwait-UAE comparison demonstrates that diversification can alleviate the risks associated with aggressive exports growth and fluctuations, while more consistent oil export flows need not be excessively diversified to avoid associated costs. However, we note that the two countries fall at the opposite poles of economic dependency on oil exports within the GCC. Petroleum exports amounted to over $90 \%$ of Kuwait's total exports and $47 \%$ of its GDP in 2018, versus $29 \%$ and $22 \%$ for the UAE, respectively (Table 2).

The oil export portfolios of Qatar and Oman exhibit significantly higher risk levels than those of their GCC peers, with standard deviation for their 2018 exports of 0.1 and 0.15 , respectively. The shapes of their efficient frontiers also suggest a sharper increase in volatility associated with potential monthly export growth. This may be less concerning for Qatar, as its oil exports have been declining in recent years, and the country derives most of its energy export revenue from natural gas. Despite the relatively higher risk profile of its oil export portfolio, Qatar has increased its diversification in recent years, reducing HHI from high concentration levels in 2013-2014 to 2262, indicating moderate concentration in 2018.

Oman, on the other hand, has been steadily increasing its oil exports, which climbed over $40 \%$ between 2008 and 2018. Most of this export growth has been absorbed by China, whose share of Oman's total oil exports reached a staggering $76.6 \%$ in 2018 , raising the country's oil export HHI to 6098. Such heavy reliance on a single buyer, along with relatively small total export volumes and intensive growth dynamics, make Oman's oil export portfolio the riskiest in the GCC.

We have also used the quadratic relationship between risk and return, Equation (9), to estimate the link between the oil export price (the measure of return) and the standard deviation of the prices to the portfolio of customers (the risk measure). We infer that the higher the price, the higher the associated dispersion of the portfolio composition, reflecting higher risk. Figure $2 \mathrm{~b}$ shows the oil export price versus risk relationships for the five GCC exporters covered in this study. The vertical axis represents oil export prices in US \$ per tonne, which is calculated on a monthly weighted average basis. The horizontal axis shows the standard deviation of prices, representing the associated risk. For instance, the return-risk combination for Saudi Arabia is 514 U.S. dollars (US \$) per tonne and a 31.9 export price standard deviation.

The estimated price levels for the 2018 Baseline scenario differ considerably among the countries in focus. Kuwait recorded the lowest level (US $\$ 497.2 /$ tonne), followed by Oman (US \$514.8/tonne), Saudi Arabia (US \$517.5/tonne), the UAE (US $\$ 539.1 /$ tonne), and Qatar (US $\$ 553.4 /$ tonne). We note that a meaningful comparison of average oil price levels for the GCC exporters is rather problematic due to underlying differences in the characteristics of their exported crudes and large fluctuations in global oil prices over the course of the year. In this regard, analysis of the slope and position of their oil portfolio frontier curves appears to be more informative.

The oil export portfolios of the UAE, Kuwait, and Saudi Arabia are the most efficient in terms of export price relative to risk. Their standard deviations of the average 2018 oil export prices fall within the range of 31.9-37.8; for export prices above US $\$ 750 /$ tonne, the risk profiles of these countries converge at a standard deviation of around 42. Saudi Arabia's portfolio has the lowest risk profile for the average monthly price levels observed in 2018, followed by the UAE's. While Kuwait's is slightly riskier, the steep slope of its efficient frontier curve suggests that its portfolio is well-positioned for a steep price increase.

As illustrated by the shape of its frontier curve, Qatar exhibits an almost linear relationship between export price and associated volatility. The country recorded an average price volatility in 2018 of 57.9 , which is the second highest among the five GCC states. As with export price growth above, Oman has the riskiest oil export portfolio of the five countries in terms of price volatility. Moreover, the shape of its frontier curve suggests an exponential increase in volatility in the event of substantial price growth. 
We note that in terms of their efficiency frontiers, the export price portfolios seem to be less affected than the export growth portfolios by diversification. Saudi Arabia, the most diversified exporter of the group, demonstrates only a slightly more efficient export price frontier than the significantly less diversified UAE or Kuwait. Comparison of the efficient frontier curves shown in Figure 2a,b shows the trade-offs between the physical supply and price components of energy security from the exporters' view. This approach can also provide insights into the exporter's priorities along these energy security dimensions. For instance, these figures indicate that Saudi Arabia focuses more on pursuing diversification and capturing major demand markets, which is reflected by its efficient export growth portfolio, rather than simply maximizing price benefits. The Kingdom also has the least vulnerable export portfolio to a potential price war among the group because it can ramp up exports without a significant increase in associated risks, while the reduction of export prices from the levels observed in this study would only have a minor impact on its portfolio volatility. At the other end of the spectrum, the export portfolios of Qatar and Oman would be highly vulnerable to such scenarios.

In general, the oil exporters covered in this study seem to demonstrate a balanced approach to minimizing risks associated with both export growth and pricing-unlike some major oil importers that tend to prioritize either the physical supply or price component of energy security [11]. However, the GCC countries vary considerably in terms of the efficiency of their oil export portfolios. In particular, the portfolios of Qatar and, especially, Oman could be further optimized to achieve more sustainable export growth with lower price risk.

\subsection{Scenario Analysis}

We estimate the impacts of potential demand shocks and logistical disruptions, according to the scenarios stated in Table 4, assessing the resilience of the five countries' optimal oil export portfolios. We use monthly average export volumes, weighted average monthly export prices, and associated volatility levels observed in 2018 as a baseline for comparison. The simulations are implemented by shocking the target variable and computing the hypothetical new return-risk efficient combination (ceteris paribus). In other words, the simulations represent new portfolio reallocations based on the assumption that a demand shock implies a new overall growth rate (the return measure) and a new standard deviation due to the shifting shares of individual importer countries (the risk measure). In the following analysis, we report the differences between the baseline and the scenario; thus, a change in return (risk) of $\mathrm{x} \%$ means that the overall export volume (standard deviation) increases by $\mathrm{x} \%$ relative to the baseline. Note that demand disruptions under these scenarios do not impact the export growth rates but rather represent a one-time shift in demand from a particular buyer or a group of buyers, resulting in a deviation from the benchmark efficient frontier.

Note also that we assume that the scenarios do not have an impact on the oil price globally, so that we implicitly rule out a quantity feedback, which is out of the scope of this study. This is because we want to focus on the portfolio re-allocation effects brought about by the simulated shock. Consequently, for the increased Chinese demand and the Malacca Strait blockade simulations, we do not test the effects of disruptions on price portfolios, as such events would have a significant systemic impact on oil prices globally (as mentioned earlier, the impact of systemic risks on the exporters' portfolios lies outside the scope of this study).

In the first simulation, we increase the monthly export volumes of the five countries to China by $20 \%$ over the Baseline 2018 scenario, without altering their exports to other destinations. These extra volumes would constitute a 5.5\% increase in China's total oil imports. A shift of this scale could hypothetically occur due to a surge in China's demand or to disruptions in its other energy import supply chains, such as pipelines to neighboring countries. We also assume that all GCC exporters are capable of providing these extra supplies-an estimated 3.9\% increase in their combined average monthly exports-given 
that their maximum monthly export volumes significantly exceed the average 2018 levels. In addition, the GCC exporters tend to maintain spare production capacity and crude oil stocks. We assess the impact of this scenario on the five countries' oil export portfolio performance-specifically, the shift in export volumes and resulting portfolio risk expressed by the standard deviation. Table 6 presents the results.

Table 6. Effects of increased oil exports to China.

\begin{tabular}{ccc}
\hline \multirow{2}{*}{ Exporter } & \multicolumn{2}{c}{ Changes Compared to Baseline 2018 } \\
\cline { 2 - 3 } & Export Volumes & Standard Deviation \\
\hline Kuwait & $4.7 \%$ & $2.2 \%$ \\
\hline Oman & $15.3 \%$ & $11.7 \%$ \\
\hline Qatar & $0.7 \%$ & $0 \%$ \\
\hline Saudi Arabia & $3.3 \%$ & $-8.8 \%$ \\
\hline UAE & $2.0 \%$ & $-1.0 \%$ \\
\hline
\end{tabular}

The impact of this surge in demand from China on the oil export portfolios of the five countries depends on the size of China's current share of their export sales. Oman's export volumes would spike $15.3 \%$, since China already accounts for over three-quarters of its oil exports. Kuwait and Saudi Arabia, whose oil exports to China in 2018 amounted to 23.7\% and $16 \%$ of their totals, would record more moderate rises of $4.7 \%$ and $3.3 \%$, respectively. The UAE and Qatar would see the least impact due to China's small shares of their exports.

However, under this scenario, portfolio risk primarily shifts according to each country's portfolio composition and the specifics of its existing bilateral export contracts with China, such as the committed volumes and regularity of shipments. Generally, an increase in export growth leads to higher risk (volatility). Oman again exhibits the largest increase $(11.7 \%)$; we note that in addition to the extreme concentration of China in its oil export portfolio, Oman already has the highest baseline risk profile (see Figure 2a). Kuwait would see a less pronounced rise in export portfolio volatility $(2.2 \%)$, while Qatar records zero impact. Conversely, the portfolio risk levels for the UAE (-1.0\%) and Saudi Arabia ( $-8.8 \%)$ decline with increased exports to China. This indicates that China is one of the most reliable buyers for these countries and is currently underrepresented in their portfolios.

In the second scenario, we reduce the share of the U.S. in the five countries' portfolios by $20 \%$ and proportionally redistribute these volumes among their other buyers. This allows us to assess the effects of portfolio restructuring without a change in volume. For the period of 2019-2021, the U.S. Energy Information Administration projects as its base case scenario that the U.S. will decrease crude oil imports at an average rate of $7.4 \%$ annually [86]. We assume that the oil imports from the GCC could drop at a faster pace due to potential substitution from less remote regions, such as the Americas or Europe. In this simulation, we also estimate the impact on export price portfolios, assuming that the decline in the U.S. imports is compensated by increased demand from other regions and, therefore, would not have a significant impact on the systemic oil price risk. The redistribution of oil export flows according to this scenario would impact only two GCC exporters, Kuwait and Saudi Arabia (Table 7). The others either exported minimal or no oil to the U.S. in 2018.

Since the affected volumes are proportionally distributed to other buyers, there is no impact on total export volumes or portfolio growth rates. However, the export portfolio risk levels (standard deviations) under this scenario do vary from the baseline. While Kuwait sees a $1 \%$ increase, Saudi Arabia actually reduces its portfolio volatility by $13 \%$.

The redistribution of the U.S.-bound export volumes also improves the performance of export price portfolios of the affected exporters. The changes in average export prices compared with the 2018 Baseline scenario are positive, though tiny (as expected, given the global nature of the crude oil market). Monthly weighted average export prices would 
increase by $0.05 \%$ (or US $\$ 0.25$ /tonne) for Saudi Arabia and $0.04 \%$ (\$0.19/tonne) for Kuwait. However, while this scenario does not measurably impact price volatility for Saudi Arabia, for Kuwait, it brings a $12.1 \%$ reduction. This can be explained by the intermittent nature of shipments to the U.S., which raises short-term volatility even though the country accounts for only $4 \%$ of Kuwait's oil export portfolio.

Table 7. Effects of decreased oil exports to the US.

\begin{tabular}{cccc}
\hline \multirow{2}{*}{ Exporter } & \multicolumn{2}{c}{ Changes Compared to Baseline 2018, \% } \\
\cline { 2 - 4 } & $\begin{array}{c}\text { Standard Deviation } \\
\text { (of Export Growth) }\end{array}$ & $\begin{array}{c}\text { Weighted Average } \\
\text { Price }\end{array}$ & $\begin{array}{c}\text { Standard Deviation } \\
\text { (of Export Price) }\end{array}$ \\
\hline Kuwait & $1.0 \%$ & $0.04 \%$ & $-12.1 \%$ \\
\hline Oman &.. &.. &.. \\
\hline Qatar &.. & $0.05 \%$ & $0 \%$ \\
\hline Saudi Arabia & $-13.0 \%$ &.. &.$\cdot$ \\
\hline UAE &.. & &
\end{tabular}

The observations derived from this scenario indicate that the expected decline in U.S. oil imports, even at a faster than expected pace, will not negatively affect the GCC exporters if offset by increased demand from importers in other regions. Notably, both Saudi Arabia and Kuwait have already been decreasing oil exports to the U.S. as a share of their portfolios, from $21.3 \%$ and $12.2 \%$ in 2008 to $12.3 \%$ and $4.0 \%$ in 2018 , respectively.

Finally, we simulate the impact on the five oil export growth portfolios of an external shock unrelated to supply/demand fluctuations in the oil market. As an example of a global supply chain disruption, we model the consequences of a blockade of the Malacca Strait, which would add an estimated 3.5 days (or approximately 20\%) to the shipping time from the GCC to major consumers in East Asia (China, Japan, South Korea, Taiwan, and the Philippines). Therefore, we assume that in the short term, monthly exports reaching these destinations would drop by $20 \%$ without substitution from other importers. In contrast with the previous scenario, the impact of the Malacca Strait blockade would be significant for all GCC exporters (see Table 8).

Table 8. Impacts of the Malacca Strait blockade.

\begin{tabular}{ccc}
\hline \multirow{2}{*}{ Exporter } & \multicolumn{2}{c}{ Changes Compared to Baseline 2018, \% } \\
\cline { 2 - 3 } & Export Volumes & Standard Deviation \\
\hline Kuwait & $-13.6 \%$ & $2.7 \%$ \\
\hline Oman & $-16.6 \%$ & $-1.4 \%$ \\
\hline Qatar & $-10.0 \%$ & $-2.8 \%$ \\
\hline Saudi Arabia & $-9.8 \%$ & $-16.1 \%$ \\
\hline UAE & $-10.0 \%$ & $-8.2 \%$ \\
\hline
\end{tabular}

Oman would suffer the largest drop in export volumes $(-16.6 \%)$, which is again due to the dominant share of China in its oil exports portfolio, followed by Kuwait $(-13.6 \%)$. The UAE, Qatar, and Saudi Arabia would also see sizeable reductions.

We expect that such a significant reduction in export volumes would lead to a partial 'de-risking' (i.e., reduction in the standard deviation) of the exporters' portfolios. Saudi Arabia demonstrates the largest such adjustment $(-16.1 \%)$, which is followed by the UAE $(-8.2 \%)$. However, Oman and Qatar record only small declines in portfolio risk levels, and Kuwait sees the standard deviation of its oil export volumes increase by $2.7 \%$. This indicates that the current composition of Kuwait's portfolio is the most vulnerable to potential disruption among the five countries. 
The observed results of the Malacca Strait blockade scenario show that the demand security of oil exporters can be affected not only by shifts in demand and importer behavior but also by the physical security and reliability of export routes and supply chains. The portfolio approach can help exporters diversify and approach their risk analysis accordingly. A sufficient level of diversification and a balanced export portfolio can also alleviate the impacts of systemic risks. For example, the ongoing COVID-19 pandemic has induced a sharp drop in overall global oil demand. However, the magnitude and dynamics of changes in oil imports have varied widely among major importing economies: in March 2020, crude oil imports increased by $4.5 \%$ in China, fell by $4.9 \%$ in the U.S., and plummeted by $50.6 \%$ in France [87]. Thus, overreliance on a given import market can magnify the vulnerability of an exporter to turbulence in world oil markets and the broader global economy.

\section{Conclusions}

This study highlights several problems inherent in the current research to the issue of energy security. First, the scope creep and the tendency to expand the energy security concept contradict the vision of key stakeholders, who consistently emphasize the security of supply and price components as their priorities. Second, some of the applied methodologies fail to capture rapid shifts in the global energy markets, in economic and geopolitical landscape, as well as the perspectives of individual energy importers or exporters and the specifics of their bilateral relationships. Finally, insufficient emphasis has been made on the exporter's perspective. As a result, energy security policy and research have often failed to address the dynamic and reciprocal nature of importer-exporter security in general and demand security in particular.

Portfolio theory can help fill these gaps in the energy security research. As shown in this study, it presents a useful tool for optimizing energy exports according to an individual exporter's priorities and captures both the export growth and price maximization components of energy demand security in foreign trade as well as the associated risks and trade-offs. We consider a positive contribution of our work the fact that the efficient frontiers and scenarios analysis using this framework allows assessing energy security taking into account specific portfolio structures. In this sense, we analyze the relation between the risk and the return, differently from the partial analysis of the risks associated with trading routes and partners.

On the other hand, we are aware that the chosen approach and, hence, the model developed in this study has certain limitations. Our analysis is focused on short-term effects, it is limited in scope (one exported fuel and five exporters), and it focused essentially only on diversifiable (non-systemic) risks. Further expansion of the model would be fairly laborand data-intensive. We think that further research in this area could focus on comprising different combinations of export fuels and supply chains, as well as on incorporating the systemic risk factors.

The oil exporters covered in this study demonstrate a balanced approach to minimizing risks associated with both export growth and pricing-unlike some major oil importers that tend to prioritize either the physical supply or price component of energy security. However, the analysis of the oil export portfolios of the five GCC countries highlights that resilience to demand and supply chain shocks varies significantly despite similar patterns in product specifications and diversification levels observed for some of the countries.

In addition to the tactical measures aimed at optimizing their export portfolios, energy exporters can improve their energy security by developing comprehensive energy policies that encompass export and demand security. This would help identify relevant challenges and threats, as well as applicable policy tools and mitigation strategies. Given the economic importance of energy exports, such policies should constitute an essential part of their broader energy, national security, and economic development agendas.

On a global scale, energy-exporting countries and the international organizations that represent their interests can help correct the observed imbalance in the concept of energy security by developing and articulating relevant comprehensive frameworks. This 
would convey the perspective of energy exporters and foster beneficial producer-consumer dialogue. Significant untapped potential exists for cooperation across a number of energy security spheres in which the interests of energy exporters and importers converge, including enhancing the security of physical supplies and supply chains, promoting transparent market mechanisms, facilitating energy investment, and reducing price volatility to increase the stability of global energy markets.

Author Contributions: C.A.B.: Conceptualization, Methodology, Software, Data curation, Writingoriginal draft. P.G.: Conceptualization, Methodology, Software, Data curation, Writing-original draft. Both authors have read and agreed to the published version of the manuscript.

Funding: This research did not receive any specific grant from funding agencies in the public, commercial, or not-for-profit sectors.

Data Availability Statement: The data presented in this study are openly available in $[43,44]$ as described in detail in Section 3.2.

Conflicts of Interest: The Authors declare that the manuscript has not been previously published, that it is not under consideration for publication elsewhere, and that its publication is approved by all co-authors. The Authors declare no conflict of interest.

\section{References}

1. Willrich, M. International energy issues and options. Annu. Rev. Energy 1976, 1, 743-772. [CrossRef]

2. Deese, D.A. Energy: Economics, politics, and security. Int. Secur. 1979, 4, 140-153. [CrossRef]

3. Yergin, D. Energy security in the 1990s. Foreign Aff. 1988, 67, 110-132. [CrossRef]

4. Sohn, I. US energy security: Problems and prospects. Energy Policy 1990, 18, 149-161. [CrossRef]

5. Toman, M.A. The Economics of energy security: Theory, evidence, policy. Handb. Nat. Resour. Energy Econ. 1993, 3, 1167-1218. [CrossRef]

6. Scheepers, M.; Seebregts, A.; De Jong, J.; Maters, H. EU Standards for Energy Security of Supply; Energy Research Centre of The Netherlands: Petten, The Netherlands, 2007. Available online: http://www.biee.org/wpcms/wpcontent/uploads/EU_ standards_for_energy_security_of_supply_2006_pres.pdf (accessed on 7 May 2020).

7. Greenleaf, J.; Harmsen, R.; Angelini, T.; Green, D.; Williams, A.; Rix, O.; Lefevre, N.; Blyth, W. Analysis of Impacts of Climate Change Policies on Energy Security. ECOFYS. 2009. Available online: http:/ / ec.europa.eu/environment/integration/energy/ pdf/cces.pdf (accessed on 7 May 2020).

8. Kemmler, A.; Spreng, D. Energy indicators for tracking sustainability in developing countries. Energy Policy 2007, 35, 2466-2480. [CrossRef]

9. Hughes, L. The Four 'R's of Energy Security; Dalhousie University: Halifax, NS, Canada, 2009. Available online: http:/ /lh.ece.dal. ca/enen/2009/ERG200902.pdf (accessed on 7 May 2020).

10. Yergin, D. Ensuring Energy Security. Foreign Affairs 2006. Available online: https://www.foreignaffairs.com/articles/2006-03-01 / ensuring-energy-security (accessed on 7 May 2020). [CrossRef]

11. Bigerna, S.; Bollino, C.A.; Galkin, P. Balancing Energy Security Priorities: Portfolio Optimization Approach to Oil Imports. Appl. Econ. 2020, 53, 555-574. [CrossRef]

12. Mohammed, M. Five Decades of Modeling Oil Price Shocks: A Critical Review. Int. Rev. Environ. Resour. Econ. 2020, 14, 241-297. [CrossRef]

13. International Energy Agency (IEA). Energy Security. 2018. Available online: https://www.iea.org/topics/energysecurity/ (accessed on 20 May 2020).

14. United Nations Development Programme (UNDP). World Energy Assessment: Energy and the Challenge of Sustainability. 2000. Available online: http:/ / www.undp.org/content/dam/aplaws/publication/en/publications/environment-energy/wwweelibrary / sustainable-energy/world-energy-assessmentenergy-and-the-challenge-of-sustainability/World \%20Energy \%20 Assessment-2000.pdf (accessed on 20 May 2020).

15. European Commission. Towards a European Strategy for the Security of Energy Supply. Available online: https://iet.jrc.ec. europa.eu/remea/sites/remea/files/green_paper_energy_supply_en.pdf (accessed on 20 May 2020).

16. Ministry of Commerce of the People's Republic of China (MOFCOM). 13th Five-Year Plan for the Development of Foreign Trade. 2017. Available online: http://english.mofcom.gov.cn/article/newsrelease/significantnews/201701/20170102500999.shtml (accessed on 20 May 2020).

17. Ministry of Trade, Industry and Energy, Republic of Korea (MOTIE). Korea Energy Master Plan: Outlook and Policies to 2035. 2014. Available online: http:/ / www.motie.go.kr/common/download.do?fid=bbs\&bbs_cd_n=72\&bbs_seq_n=209286\&file_seq_n=2 (accessed on 25 May 2020).

18. Sovacool, B.K. Evaluating energy security in the Asia Pacific: Towards a more comprehensive approach. Energy Policy 2011, 39, 7472-7479. [CrossRef] 
19. Global Energy Institute. Index of U.S. Energy Security Risk. 2017. Available online: https://www.globalenergyinstitute.org/ sites/default/files/USIndexFinal2PDF.pdf (accessed on 25 May 2020).

20. Zhang, X.N.; Zhong, Q.-Y.; Qu, Y.; Li, H.-L. Liquefied natural gas importing security strategy considering multi-factor: A multi-objective programming approach. Expert Syst. Appl. 2017, 87, 56-69. [CrossRef]

21. Rioux, B.; Galkin, P.; Wu, K. An Economic Analysis of China's Domestic Crude Oil Supply Policies. Chin. J. Popul. Resour. Environ. 2019, 17, 217-228. [CrossRef]

22. Garrison, J.A.; Redd, S.B.; Carter, R.G. Energy security under conditions of uncertainty: Simulating a comparative bureaucratic politics approach. J. Political Sci. Educ. 2010, 6, 19-48. [CrossRef]

23. Hughes, L.; Phillip, Y.L. The politics of energy. Annu. Rev. Political Sci. 2013, 16, 449-469. [CrossRef]

24. Organization of the Petroleum Exporting Countries (OPEC) 2012. OPEC Statute. Available online: https://www.opec.org/opec_ web/static_files_project/media/downloads/publications/OPEC_Statute.pdf (accessed on 20 May 2020).

25. Organization of the Petroleum Exporting Countries (OPEC). Energy Security and Supply. 4 February 2008. Available online: https:/ / www.opec.org/opec_web/en/press_room/862.html (accessed on 20 May 2020).

26. Organization of the Petroleum Exporting Countries (OPEC). Energy Security: A Global Perspective. 27 July 2006. Available online: https:/ / www.opec.org/opec_web/en/press_room/996.html (accessed on 20 May 2020).

27. Organization of the Petroleum Exporting Countries (OPEC). Security Breeds Security. In OPEC Bulletin Commentary, JanuaryFebruary 2006; Ueberreuter Print and Digimedia: Vienna, Austria, 2006. Available online: https://www.opec.org/opec_web/en/ press_room/853.html (accessed on 20 May 2020).

28. Gas Exporting Countries Forum (GECF). Gas Exporting Countries Forum Long-term Strategy. 2017. Available online: https://www.gecf.org/_resources/files/events/the-gas-exporting-countries-forum-long-term-strategy/gecf_lts_document_ 14122017.pdf (accessed on 21 May 2020).

29. Gas Exporting Countries Forum (GECF). Global Gas Outlook. 2018. Available online: https://www.enerjiportali.com/wpcontent/ uploads / 2018/12/2018-Global-Gas-Outlook.pdf (accessed on 21 May 2020).

30. Peña-Ramos, J.A.; Bagus, P.; Amirov-Belova, D. The North Caucasus Region as a Blind Spot in the "European Green Deal": Energy Supply Security and Energy Superpower Russia. Energies 2021, 14, 17. [CrossRef]

31. Minenergo. The Ministry of Energy of the Russian Federation, Министерство ЭнергетикиРоссийскойФедерации(Минэнерго). Доктрина энергетической безопасностиРоссийскойФедерации[The Doctrine of Energy Security of the Russian Federation]. 2019. Available online: https:/ / minenergo.gov.ru/node/14766 (accessed on 25 May 2020).

32. Aminzadeh, E.; Khodaparast, N. Legal Approach to Energy Security of Iran: With Special References to Crude Oil and Gas. J. East Asia Int. Law 2019, 12, 71-90. [CrossRef]

33. Department of Resources, Energy and Tourism of the Government of Australia. National Energy Security Assessment. 2011. Available online: https:/ / www.energy.gov.au/sites/default/files/national-energy-security-assessment-2011_0.pdf (accessed on 21 May 2020).

34. Ministry of Natural Resources of Canada. The Energy Safety and Security Act. 2016. Available online: https://laws-lois.justice. gc.ca/PDF/2015_4.pdf (accessed on 21 May 2020).

35. Energy Commission of Nigeria. National Energy Policy. 2018. Available online: http://www.energy.gov.ng/Energy_Policies_ Plan/National\%20Energy\%20Policy.pdf (accessed on 25 May 2020).

36. Energy Commission of Nigeria. National Energy Masterplan. 2014. Available online: http://www.energy.gov.ng/Energy_ Policies_Plan/Draft \%20 (accessed on 25 May 2020).

37. Kruyt, B.; van Vuuren, D.; de Vries, H.; Groenenberg, H. Indicators for energy security. Energy Policy 2009, 37, $2166-2181$. [CrossRef]

38. Kanchana, K.; Unesaki, H. ASEAN energy security: An indicator-based assessment. Energy Procedia 2014, 56, 163-171. [CrossRef]

39. Ang, B.; Choong, W.; Ng, A. Energy security: Definitions, dimensions and indexes. Renew. Sustain. Energy Rev. 2015, 42, 1077-1093. [CrossRef]

40. Spero, J.E. Energy self-sufficiency and national security. Proc. Acad. Political Sci. 1973, 31, 123-136. [CrossRef]

41. Dike, J.C. Measuring the Security of Energy Exports Demand in OPEC Economies. Energy Policy 2013, 60, 594-600. [CrossRef]

42. International Energy Agency (IEA). IEA Atlas of Energy. 2019. Available online: http:/ / energyatlas.iea.org (accessed on 23 December 2019).

43. World Bank. World Integrated Trade Solution. 2019. Available online: https://wits.worldbank.org (accessed on 19 December 2019).

44. International Trade Centre (ITC). Trade Map. 2019. Available online: https://www.trademap.org/ (accessed on 19 December 2019).

45. CEIC. Global Database. 2019. Available online: https://insights.ceicdata.com (accessed on 19 December 2019).

46. Pregger, T.; Lavagno, E.; Labriet, M.; Seljom, P.; Biberacher, M.; Blesl, M.; Trieb, F.; O'Sullivan, M.; Gerboni, R.; Schranz, L.; et al. Resources, capacities and corridors for energy imports to Europe. Int. J. Energy Sect. Manag. 2011, 5, 125-156. [CrossRef]

47. Zhang, L.; Bai, W. Risk assessment of China's natural gas Importation: A supply chain perspective. SAGE Open 2020, 10. [CrossRef]

48. Bakdolotov, A.; De Miglio, R.; Akhmetbekov, Y.; Baigarin, K. Techno-economic modelling to strategize energy exports in the Central Asian Caspian region. Heliyon 2017, 3, e00283. [CrossRef] 
49. Geng, Z. Russian energy strategies in the natural gas market for energy security. Int. J. Energy Econ. Policy 2020, 11, 62-66. [CrossRef]

50. United States Department of Justice. Herfindahl-Hirschman Index. 2018. Available online: https://www.justice.gov/atr/ herfindahl-hirschman-index (accessed on 27 November 2019).

51. Kalt, J.P.; Robert, S.S. The role of governmental incentives in energy production: A historical overview. Ann. Rev. Energy 1980, 5, 1-32. [CrossRef]

52. Cone, B.W. A historical perspective of federal incentives to stimulate energy production. Energy 1982, 7, 51-60. [CrossRef]

53. Marks, R.E. Australian energy policy and conservation. In IFAC Proceedings Volumes; Elsevier: Amsterdam, The Netherlands, 1989; Volume 22, pp. 409-415. [CrossRef]

54. Khatib, H.; Energy security. World Energy Assessment: Energy and the Challenge. UNDP, $2015 . \quad$ Available online: https:/ / www.google.com/url?sa=t\&rct=j\&q=\&esrc=s\&source=web\&cd=\&cad=rja\&uact=8\&ved=2ahUKEwjut6uF3 OLxAhWvw4sKHcplAIcQFnoECAQQAA\&url=https\%3A\%2F\%2Fwww.undp.org\%2Fcontent \%2Fdam\%2Fundp \%2Flibrary\% 2FEnvironment $\% 2520$ and $\% 2520$ Energy $\% 2 F S u s t a i n a b l e \% 2520$ Energy $\% 2$ Fwea $\% 25202000 \% 2 F c h a p t e r 4 . p d f \& u s g=A O v V a w 2 j 8$ VwuUmNJFtFO1n69u2u4 (accessed on 13 June 2021).

55. National Energy Board of Canada. Canada's Energy Future. Infrastructure Changes and Challenges to 2020; 2009. Available online: https:/ / www.cer-rec.gc.ca/en/data-analysis/canada-energy-future/archive/2009/2009-infrastructure-changeschallenges/2009nfrstrctrchngchllng-eng.pdf (accessed on 13 April 2020).

56. Balza, L.; Espinasa, R. Oil Sector Performance and Institutions: The Case of Latin America. Inter-American Development Bank, 2014. Available online: https://publications.iadb.org/publications/english/document/Oil-Sector-Performance-andInstitutions-The-Case-of-Latin-America.pdf (accessed on 13 April 2020).

57. Oxford Business Group. Investments in Spare Energy Capacity Aim to Protect Saudi Arabia from Future oil and Gas Crises. 2018. Available online: https:/ / oxfordbusinessgroup.com/analysis/building-cushion-investments-spare-capacity-aim-protectsaudi-arabia-future-oil-and-gas-crises (accessed on 10 May 2020).

58. Erickson, E.W.; Millsaps, S.W.; Spann, R.M. Oil supply and tax incentives. Brook. Pap. Econ. Act. 1974, 2, 449-493. [CrossRef]

59. Deloitte. Tax Credits and Incentives for Oil \& Gas Producers in a Low-Price Environment. 2017. Available online: https://www2 .deloitte.com/content/dam/Deloitte/us/Documents/Tax/us-tax-credits-and-incentives-for-oil-and-gas-producers.pdf (accessed on 23 December 2019).

60. International Monetary Fund (IMF). Issues in Domestic Petroleum Pricing in Oil Producing Countries. IMF Working Paper. 2002. Available online: https://www.imf.org/external/pubs/ft/wp/2002/wp02140.pdf (accessed on 15 April 2020).

61. Kpodar, K.K.; Fabrizio, S.; Eklou, K.M. Export Competitiveness-Fuel Price Nexus in Developing Countries: Real or False Concern? 2019. Available online: https://www.imf.org/en/Publications/WP/Issues/2019/02/04/Export-CompetitivenessFuel-Price-Nexus-in-Developing-Countries-Real-or-False-Concern-46424 (accessed on 15 April 2020).

62. Vivoda, V. LNG import diversification and energy security in Asia. Energy Policy 2019, 129, 967-974. [CrossRef]

63. Karatayev, M.; Hall, S. Establishing and comparing energy security trends in resource-rich exporting nations (Russia and the Caspian Sea region). Resour. Policy 2020, 68, 101746. [CrossRef]

64. Daniel, J. Hedging Government Oil Price Risk. IMF eLibrary. 2001. Available online: https:/ / www.elibrary.imf.org/view / IMF0 01/03085-9781451859416/03085-9781451859416/03085-9781451859416_A001.xml?language=en\&redirect=true (accessed on 9 May 2020).

65. Bacon, R.; Masami, K. Coping with Oil Price Volatility. Energy Sector Management Assistance Program. 2008. Available online: https://www.esmap.org/sites/default/files/esmap-files/8142008101202_coping_oil_price.pdf (accessed on 9 May 2020).

66. Moneef, M. Vertical integration strategies of the national oil companies. Dev. Econ. 2007, 36, 203-222. [CrossRef]

67. Mitrova, T. Energy security and evolution of gas markets. Energy Environ. 2008, 19, 1123-1130. [CrossRef]

68. Markowitz, H. Portfolio Selection. J. Financ. 1952, 7, 77-91.

69. Bar-Lev, D.; Katz, S. A portfolio approach to fossil fuel procurement in the electric utility industry. J. Financ. 1976, 31, 933-947. [CrossRef]

70. Humphreys, B.H.; Katherine, T.M. Reducing the impacts of energy price volatility through dynamic portfolio selection. The Energy J. 1998, 19, 107-131. [CrossRef]

71. Awerbuch, S.; Berger, M. Applying Portfolio Theory to EU Electricity Planning and Policy-Making. IEA/EET Working Paper. 2003. Available online: https://awerbuch.com/shimonpages/shimondocs/iea-portfolio.pdf (accessed on 21 June 2021).

72. Gunther, W.; Madlener, R. The benefit of regional diversification of cogeneration investments in Europe: A mean-variance portfolio analysis. Energy Policy 2010, 38, 7911-7920. [CrossRef]

73. Medimorec, D.; Tomsic, Z. Portfolio theory application in wind potential assessment. Renew. Energy 2015, 76, 494-502. [CrossRef]

74. Canelas, E.; Pinto-Varela, T.; Sawik, B. Electricity Portfolio Optimization for Large Consumers: Iberian Electricity Market Case Study. Energies 2020, 13, 2249. [CrossRef]

75. Sun, X.; Hao, J.; Li, J. Multi-objective optimization of crude oil-supply portfolio based on interval prediction data. Ann. Oper. Res. 2020, 1-29. [CrossRef]

76. Sawik, B. Downside Risk Approach for Multi-Objective Portfolio Optimization. In Operations Research Proceedings 2011; Klatte, D., Lüthi, H.J., Schmedders, K., Eds.; Springer: Berlin/Heidelberg, Germany, 2012. [CrossRef] 
77. Faia, R.; Pinto, T.; Vale, Z.; Corchado, J.M. Portfolio optimization of electricity markets participation using forecasting error in risk formulation. Int. J. Electr. Power Energy Syst. 2021, 129, 106739. [CrossRef]

78. Bigerna, S.; Bollino, C.A.; Polinori, P. Oil import portfolio risk and spillover volatility. Resour. Policy 2021, 70, 101976. [CrossRef]

79. Wu, G.; Wei, Y.-M.; Fan, Y.; Liu, L.-C. An empirical analysis of the risk of crude oil imports in China using improved portfolio approach. Energy Policy 2007, 35, 4190-4199. [CrossRef]

80. Wang, J.; Sun, X.; Li, J.; Chen, J.; Liu, C. Has China's oil-import portfolio been optimized from 2005 to 2014 ? A perspective of cost-risk tradeoff. Comput. Ind. Eng. 2018, 126, 451-464. [CrossRef]

81. Ge, F.; Fan, Y. Quantifying the risk to crude oil imports in China: An improved portfolio approach. Energy Econ. 2013, 40, 72-80. [CrossRef]

82. Wabiri, N.; Amusa, H. Quantifying South Africa's crude oil import risk: A multi-criteria portfolio model. Econ. Modeling 2010, 27, 445-453. [CrossRef]

83. Nowrouzi, A.; Panahi, M.; Ghaffarzadeh, H.; Ataei, A. Optimizing Iran's natural gas export portfolio by presenting a conceptual framework for non-systematic risk based on portfolio theory. Energy Strategy Rev. 2019, 26, 100403. [CrossRef]

84. Moreno, M.; Novales, A.; Platania, F. Long-term Swings and Seasonality in Energy Markets. Eur. J. Oper. Res. 2019, 279, 1011-1023. [CrossRef]

85. Inchauspe, J.; Li, J.; Park, J. Seasonal Patterns of Global Oil Consumption: Implications for Long Term Energy Policy. J. Policy Modeling 2020, 42, 536-556. [CrossRef]

86. U.S. Energy Information Administration (EIA). NEMS Overview and Brief Description of Cases. 2019. Available online: https: / / www.eia.gov / outlooks/archive/aeo16/appendixe.php (accessed on 13 June 2021).

87. International Trade Centre (ITC). Trade Map. 2020. Available online: https:/ / www.trademap.org/ (accessed on 3 December 2020). 